\title{
Inhibition of Protein Synthesis in Reticulocyte Lysates by Trichodermin
}

\author{
By CHRISTOPHER J. CARTER, MICHAEL CANNON and KELVIN E. SMITH \\ Department of Biochemistry, University of London King's College, \\ Strand, London WC2R 2LS, U.K.
}

(Received 5 August 1975)

\begin{abstract}
1. The effect of trichodermin as an inhibitor of eukaryotic protein synthesis was studied in a reticulocyte cell-free system. 2. Trichodermin at a concentration of $25 \mu \mathrm{g} / \mathrm{ml}$ inhibits total protein synthesis instantaneously and stabilizes polyribosome profiles. Conversely, at a concentration of $0.25 \mu \mathrm{g} / \mathrm{ml}$ the drug inhibits total protein synthesis by only $70-75 \%$ and allows $30-35 \%$ breakdown of the polyribosomes in the system. 3. These effects were compared with those produced by two other drugs (pactamycin and anisomycin) examined under conditions identical with those used for trichodermin. 4. It is concluded that at high concentration $(25 \mu \mathrm{g} / \mathrm{ml})$ trichodermin inhibits elongation at the level of the peptidyl transferase catalytic centre. However, at low concentration $(0.25 \mu \mathrm{g} / \mathrm{ml})$ trichodermin inhibits peptide-bond formation at the initiation stage and inhibits elongation only secondarily, although at the lower concentration both inhibitory effects are incomplete. 5. The results presented exclude any possibility that, under the conditions used here in vitro, trichodermin can act preferentially as an inhibitor of the termination step in protein synthesis.
\end{abstract}

The 12,13-epoxytrichothecenes are a group of toxins produced by various fungi and they are potent inhibitors of eukaryotic protein synthesis (Bamburg \& Strong, 1971; Ueno, 1970). The precise modes of inhibition vary subtly for compounds within the series (Cundliffe et al., 1974). Thus one subgroup, containing T-2 toxin and verrucarin A, inhibits protein synthesis at the initiation stage or shortly thereafter, and a second subgroup, containing trichodermin, inhibits elongation or termination.

There is now firm evidence from many sources that the 12,13-epoxytrichothecenes inhibit the peptidyl transferase catalytic centre (Carrasco et al., 1973; Tate \& Caskey, 1973). However, T-2 toxin, although capable of inhibiting polypeptidechain initiation fails to inhibit the puromycin reaction with polyribosomes carrying long polypeptide chains (Smith et al., 1975). Conversely, trichodermin inhibits both these reactions (Tate \& Caskey, 1973; Schindler, 1974) and hence has been classified as a general inhibitor of the peptidyl transferase catalytic centre. Despite these facts, however, the preferred mode of action of trichodermin has been the subject of a mild controversy. Thus it has been claimed that trichodermin is a relatively specific inhibitor of peptide-chain termination by studies both in vitro and in vivo using mammalian and yeast systems (Wei et al., 1974; Stafford \& McLaughlin, 1973).

In the present work we have carried out a careful study of the effect of trichodermin on protein synthesis in the reticulocyte cell-free system. We have concentrated on examining polyribosome profiles in this system and have considered how these profiles are affected by trichodermin added at various concentrations. We have used two other drugs, pactamycin and anisomycin, for comparison, since the modes of action of these drugs as inhibitors of protein synthesis have been wellcharacterized (Grollman, 1967; Lodish et al., 1971; Stewart-Blair et al., 1971). Our results show clearly that trichodermin, added at high concentrations, completely stabilizes polyribosome profiles in a fashion characteristic of a potent inhibitor of the peptidyl transferase catalytic centre (Cundliffe et al., 1974). At low concentrations of trichodermin, however, there is a partial breakdown of polyribosomes, implying that under these conditions the drug can inhibit initiation. Our data do not lend support to the hypothesis that trichodermin acts primarily as an inhibitor of the termination reaction in vitro.

\section{Experimental}

Preparation of lysates and cell-free protein-synthesizing systems

Rabbit reticulocyte lysates were prepared exactly as described by Smith et al. (1975). A cell-free protein-synthesizing system was prepared also as described by Smith et al. (1975) except that $5 \mu \mathrm{Ci}$ of L- $\left[2,3-{ }^{3} \mathrm{H}\right]$ valine was added to measure protein synthesis. Further, the incubation temperature was $20^{\circ} \mathrm{C}$ and the volume of the samples removed was $50 \mu \mathrm{l}$. The incubation temperature of $20^{\circ} \mathrm{C}$ was 
chosen to slow down the rate of protein synthesis in the lysate, hence producing a slower 'run down' in the control polyribosome profiles, and to maintain continual initiation (M. Clemens, personal communication). Also we have observed that dimethyl sulphoxide, in which one of the drugs was dissolved, had no effect on the cell-free system at this temperature, when added at the concentrations stated. The $50 \mu \mathrm{l}$ samples were withdrawn, pipetted on to $2.5 \mathrm{~cm}$ discs of Whatman $3 \mathrm{MM}$ paper, processed and assayed for radioactivity as described by Smith et al. (1975). Counting efficiency was at $8 \%$.

\section{Analysis of polyribosome profiles on sucrose gradients}

Linear $10-30 \%(w / v)$ sucrose gradients were prepared (vol. $5 \mathrm{ml}$ ) in buffer containing (at final concentrations): $20 \mathrm{~mm}-\mathrm{Tris} / \mathrm{HCl}\left(\mathrm{pH} 7.2\right.$ at $20^{\circ} \mathrm{C}$ ), $80 \mathrm{~mm}-\mathrm{KCl}, 3 \mathrm{~mm}$-magnesium acetate, $1 \mathrm{~mm}$-dithiothreitol and 0.1 mM-EDTA. Samples $(50 \mu l)$ were removed from incubation mixtures at the times specified and diluted to $250 \mu \mathrm{l}$ with the above buffer (ice-cold) containing cycloheximide (final concentration $100 \mu \mathrm{g} / \mathrm{ml}$ ). The samples were layered on gradients and centrifuged for $45 \mathrm{~min}$ at $41000 \mathrm{rev}$./ min in a Spinco SW 50.1 rotor. Gradients were analysed in an Isco gradient analyser, using a $50 \mathrm{ml}$ syringe, by upward displacement with $60 \%$ glycerol. The gradients were eluted at $0.625 \mathrm{ml} / \mathrm{min}$ with a chart speed of $0.5 \mathrm{~mm} / \mathrm{s}$. This gave a run time for each gradient of $8 \mathrm{~min}$ and all tracings were recorded over $24 \mathrm{~cm}$ of chart paper.

\section{Antibiotics}

Trichodermin (mol.wt. 292), T-2 toxin, pactamycin (mol.wt. 558) and anisomycin (mol.wt. 265) were generously provided by Dr. Eric Cundliffe, Dept. of Molecular Pharmacology, University of Cambridge, U.K. The drugs were dissolved in water, except for T-2 toxin, which was dissolved in dimethyl sulphoxide $(45 \%)$. When dimethyl sulphoxide was added its final concentration in reaction mixtures was always less than $0.5 \%(\mathrm{v} / \mathrm{v})$.

\section{Radioactive chemicals}

L- $\left[2,3-{ }^{3} \mathrm{H}\right]$ Valine (specific radioactivity $19 \mathrm{Ci} / \mathrm{mmol}$ ) was obtained from The Radiochemical Centre, Amersham, Bucks., U.K.

\section{Results and Discussion}

Cundliffe et al. (1974) have shown that trichodermin stabilizes polyribosomes in HeLa cells and
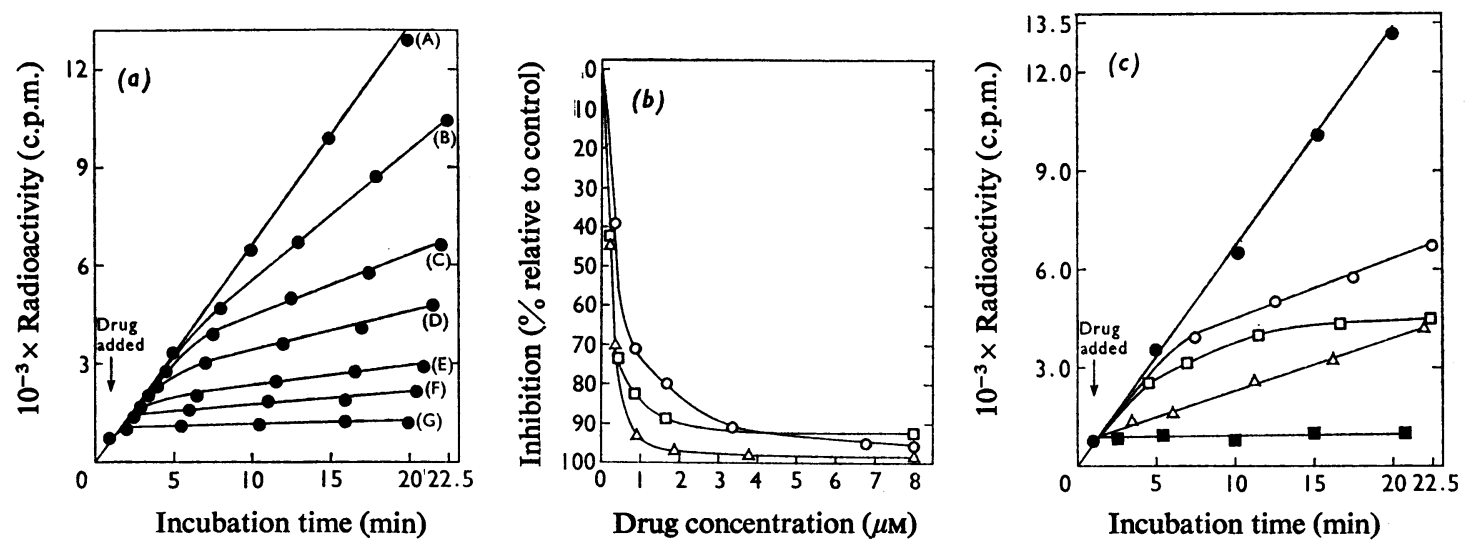

Fig. 1. Inhibition of protein synthesis by trichodermin, pactamycin and anisomycin

Incubation mixtures were prepared as described in the Experimental section and incubated at $20^{\circ} \mathrm{C}$. Drugs were added as indicated by the arrows. Samples $(50 \mu \mathrm{l})$ were removed at the times shown and processed as described in the Experimental section. (a) Time-courses showing inhibition of protein synthesis by trichodermin at various concentrations. Control (A); trichodermin at: $0.1 \mu \mathrm{g} / \mathrm{ml}$ (B) $; 0.25 \mu \mathrm{g} / \mathrm{ml}$ (C); $0.50 \mu \mathrm{g} / \mathrm{ml}$ (D); $1 \mu \mathrm{g} / \mathrm{ml}$ (E); $2 \mu \mathrm{g} / \mathrm{ml}$ (F); $4 \mu \mathrm{g} / \mathrm{ml}$ (G). (b) Linear rates of inhibition of protein synthesis produced by various concentrations of trichodermin (O), pactamycin ( $\square$ ) and anisomycin $(\Delta)$. (c) Time-courses showing inhibition of protein synthesis by selected concentrations of trichodermin, pactamycin and anisomycin. Control (O);0.25 $\mu \mathrm{g}$ of trichodermin $/ \mathrm{ml}(0) ; 0.25 \mu \mathrm{g}$ of pactamycin $/ \mathrm{ml}(\square) ; 0.1 \mu \mathrm{g}$ of anisomycin $/ \mathrm{ml}(\triangle) ; 25 \mu \mathrm{g}$ of trichodermin $/ \mathrm{ml}(\square)$. For pactamycin $(200 \mu \mathrm{g} / \mathrm{ml})$ and anisomycin $(40 \mu \mathrm{g} / \mathrm{ml})$ the curves were indistinguishable from that with trichodermin $(25 \mu \mathrm{g} / \mathrm{ml})$. The low concentrations of drugs gave $70-75 \%$ inhibition of protein synthesis. The high concentrations $(\square)$ gave $100 \%$ inhibition. 
in yeast spheroplasts. These studies were performed with high trichodermin concentrations $(25 \mu \mathrm{g} / \mathrm{ml})$, a concentration that inhibits protein synthesis totally under the conditions used. We decided therefore to investigate the effects of trichodermin at concentrations that were less inhibitory towards protein synthesis. Further, we chose the reticulocyte cell-free system for this study. The system is relatively wellcharacterized and is currently being used by us in our companion work with other 12,13-epoxytrichothecenes (Smith et al., 1975; M. Cannon, K. E. Smith \& C. J. Carter, unpublished work).

The effects of trichodermin, added at low concentrations, on reticulocyte polyribosome profiles were investigated and compared with effects produced by two other antibiotics, anisomycin and pactamycin, at concentrations producing a similar inhibitory response to protein synthesis. Suitable drug concentrations, producing submaximum inhibition of protein synthesis $(70-75 \%)$, were determined for each of the three antibiotics. Fig. 1(a) shows a series of complete time-courses, which measure protein synthesis, for trichodermin concentrations ranging from 0.1 to $4 \mu \mathrm{g} / \mathrm{ml}$ compared with a control and indicates that residual protein synthesis occurs at all concentrations shown. At trichodermin concentrations above $4 \mu \mathrm{g} / \mathrm{ml}, 100 \%$ inhibition of protein synthesis was apparent. The kinetics of Fig. 1(a) indicate that for trichodermin concentrations below $4 \mu \mathrm{g} / \mathrm{ml}$ a lag period occurs before the drug exerts its maximum effect. The duration of the lag period increases with decreasing drug concentration and irrespective of the duration of this lag, thereafter incorporation proceeds linearly with time for a further $15-20 \mathrm{~min}$ in all cases. Similar time-courses were run for the other two antibiotics (results not shown) and Fig. 1(b) shows a comparison of the degrees of inhibition produced by increasing drug concentrations for all three drugs. Our system is very sensitive to inhibition by trichodermin, a noteworthy point, since other workers using a similar system obtained an apparent maximum of only $70 \%$ inhibition of protein synthesis with trichodermin added at high concentration $(140 \mu \mathrm{M})$. However, we are confident of repeated initiations (see the Experimental section) in our protein-synthesizing system, as indicated by high amounts of incorporation and stability of control polyribosome profiles. Differences in inhibition values between our work and that of others (Wei et al., 1974) may be related to this fact.

Fig. 1(c) shows a comparison of the kinetics produced by the three drugs at concentrations producing $70-75 \%$ rate inhibition of protein synthesis and at concentrations producing $100 \%$ rate inhibition. In the former case pactamycin produces a similar (but shorter) lag compared with that observed with trichodermin, whereas anisomycin produces no initial lag. At 100\% inhibition, all three antibiotics exhibit no initial lag and show virtually identical kinetics, inhibiting protein synthesis instantaneously.

Having established reproducible kinetics of inhibition for the three drugs at the various concentrations used we then studied the effects of these drugs on polyribosome profiles in the reticulocyte cell-free system. This technique provides a useful means to distinguish between various types of inhibitory response. Thus a potent inhibitor of elongation should stabilize the profile and conversely an inhibitor of initiation should allow 'run off' of ribosomes from mRNA (Cundliffe et al., 1974). An inhibitor of termination should theoretically shift the profile towards polyribosomes of increasing size, assuming that initiation is occurring in the inhibited system.

Fig. 2 shows the effects on polyribosome profiles of trichodermin added at concentrations of $0.25 \mu \mathrm{g}$ and $25 \mu \mathrm{g} / \mathrm{ml}$ for different incubation times. Figs. $2(a), 2(b)$ and $2(d)$ illustrate control profiles obtained 1,15 and $30 \mathrm{~min}$ respectively after starting the incubation. There is a slow breakdown of polyribosomes with time, as indicated by the sequential conversion of large polyribosomes into ones of smaller size with a corresponding slight increase in $80 \mathrm{~S}$ monomers. Fig. $2(f)$ shows a profile at $15 \mathrm{~min}$ of a sample previously treated with $25 \mu \mathrm{g}$ of trichodermin $/ \mathrm{ml}$ added at $1 \mathrm{~min}$. Stabilization of the polyribosomes has clearly occurred (cf. Fig. 2a). Figs 2(c) and 2(e) show profiles at 15 and $30 \mathrm{~min}$ respectively of a sample previously treated with $0.25 \mu \mathrm{g}$ of trichodermin $/ \mathrm{ml}$ added at $1 \mathrm{~min}$. These profiles are distinctly different from that shown in Fig. $2(f)$ and show a considerable degree of polyribosome breakdown, certainly greater than that shown by the controls (cf. Figs. $2 b$ and $2 d$ ). By comparing the areas under the peaks in Figs. 2(b) and 2(c) we have calculated that there has been approximately $35 \%$ breakdown of the polyribosomes. The absence of further breakdown between the 15 and $30 \mathrm{~min}$ time-points (cf. Figs. $2 c$ and $2 e$ ) suggests that stabilization of the profile occurs after the initial breakdown, thus resulting in a steady-state situation in which a decreased rate of protein synthesis is maintained (cf. Fig. 1a),

To determine if the above observations were specific for trichodermin or to decide whether or not this was a general observation which would apply to other elongation inhibitors, similar experiments were performed using high and low concentrations of the antibiotics anisomycin and pactamycin. The former antibiotic is a wellcharacterized inhibitor of the elongation phase of eukaryotic protein synthesis (Grollman, 1967) and specifically inhibits peptidyl transferase. Pactamycin inhibits both $80 \mathrm{~S}$ and $70 \mathrm{~S}$ ribosomal function but 

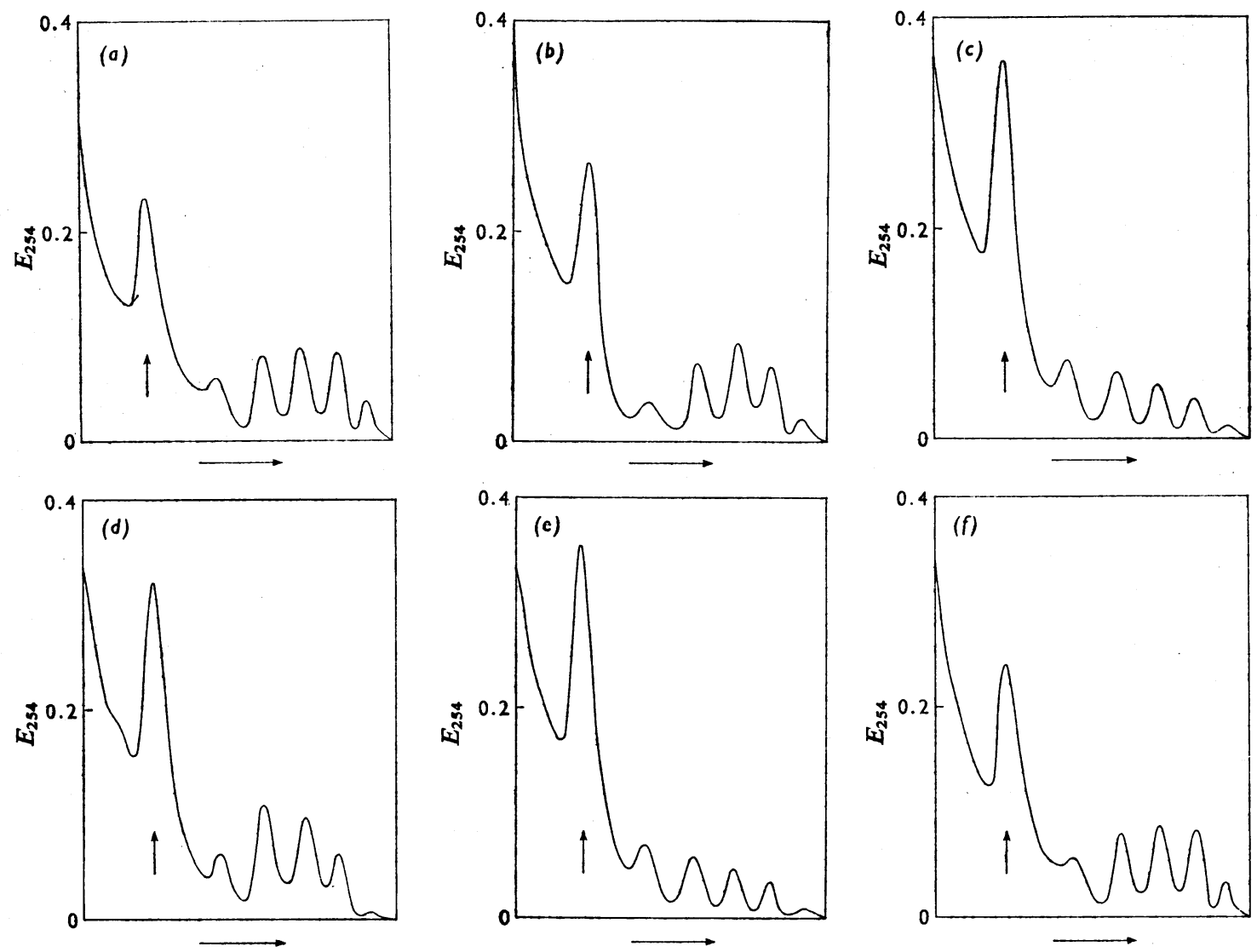

Fig. 2. Effect of trichodermin on polyribosome profiles in reticulocyte lysates

Incorporation mixtures were prepared as described in the Experimental section and incubated at $20^{\circ} \mathrm{C}$ with two different concentrations of trichodermin, added after $1 \mathrm{~min}$ incubation. Samples were removed at 15 and $30 \mathrm{~min}(0.25 \mu \mathrm{g}$ of trichodermin $/ \mathrm{ml})$ and $15 \mathrm{~min}(25 \mu \mathrm{g}$ of trichodermin $/ \mathrm{ml})$. Controls, without added drug, were removed at 1,15 and $30 \mathrm{~min}$. Samples were analysed on sucrose gradients as described in the Experimental section. (a) Control, 1 min incubation; (b) control, $15 \mathrm{~min}$ incubation; (c) $0.25 \mu \mathrm{g}$ of trichodermin $/ \mathrm{ml}, 15 \mathrm{~min}$ incubation; (d) control, 30 min incubation; (e) $0.25 \mu \mathrm{g}$ of trichodermin/ml, 30 min incubation; $(f) 25 \mu \mathrm{g}$ of trichodermin $/ \mathrm{ml}, 15 \mathrm{~min}$ incubation. In all cases the position of the $80 \mathrm{~S}$ ribosome peak is marked with a vertical arrow. The horizontal arrow under the abscissa represents the direction of sedimentation of polyribosomes.

appears to have a dual mode of action. At selective low concentrations (0.1-1 $\mu \mathrm{M})$ pactamycin induces ribosomal 'run off' by apparently inhibiting initiation, whereas at higher concentrations $(10 \mu \mathrm{M})$ stabilization of polyribosome profiles is observed indicating an additional effect on elongation (Lodish et al., 1971; Stewart-Blair et al., 1971).

Figs. 3(a) and $3(b)$ show profiles at $15 \mathrm{~min}$ of samples previously treated with $40 \mu \mathrm{g}$ and $0.1 \mu \mathrm{g}$ of anisomycin $/ \mathrm{ml}$ respectively added at $1 \mathrm{~min}$. Both profiles show essentially the same pattern; no breakdown of polyribosomes has occurred at either concentration. If anything these profiles suggest (cf. Fig. $2 b$ ) that a slight build-up has taken place. Even at very high concentrations of anisomycin $(250 \mu \mathrm{g} / \mathrm{ml})$ essentially identical profiles were observed (results not shown). Figs. 3(c) and 3(d) show profiles at $15 \mathrm{~min}$ of samples previously treated with $200 \mu \mathrm{g}$ and $0.25 \mu \mathrm{g}$ of pactamycin $/ \mathrm{ml}$ respectively, added at $1 \mathrm{~min}$. The high pactamycin concentration (Fig. 3c) stabilizes the profile, as was observed with high concentrations of trichodermin and anisomycin, whereas low concentrations of pactamycin (Fig. 3d) produce extensive polyribosome breakdown, an effect characteristic of an inhibitor of initiation (Cundliffe et al., 1974). This breakdown was con- 

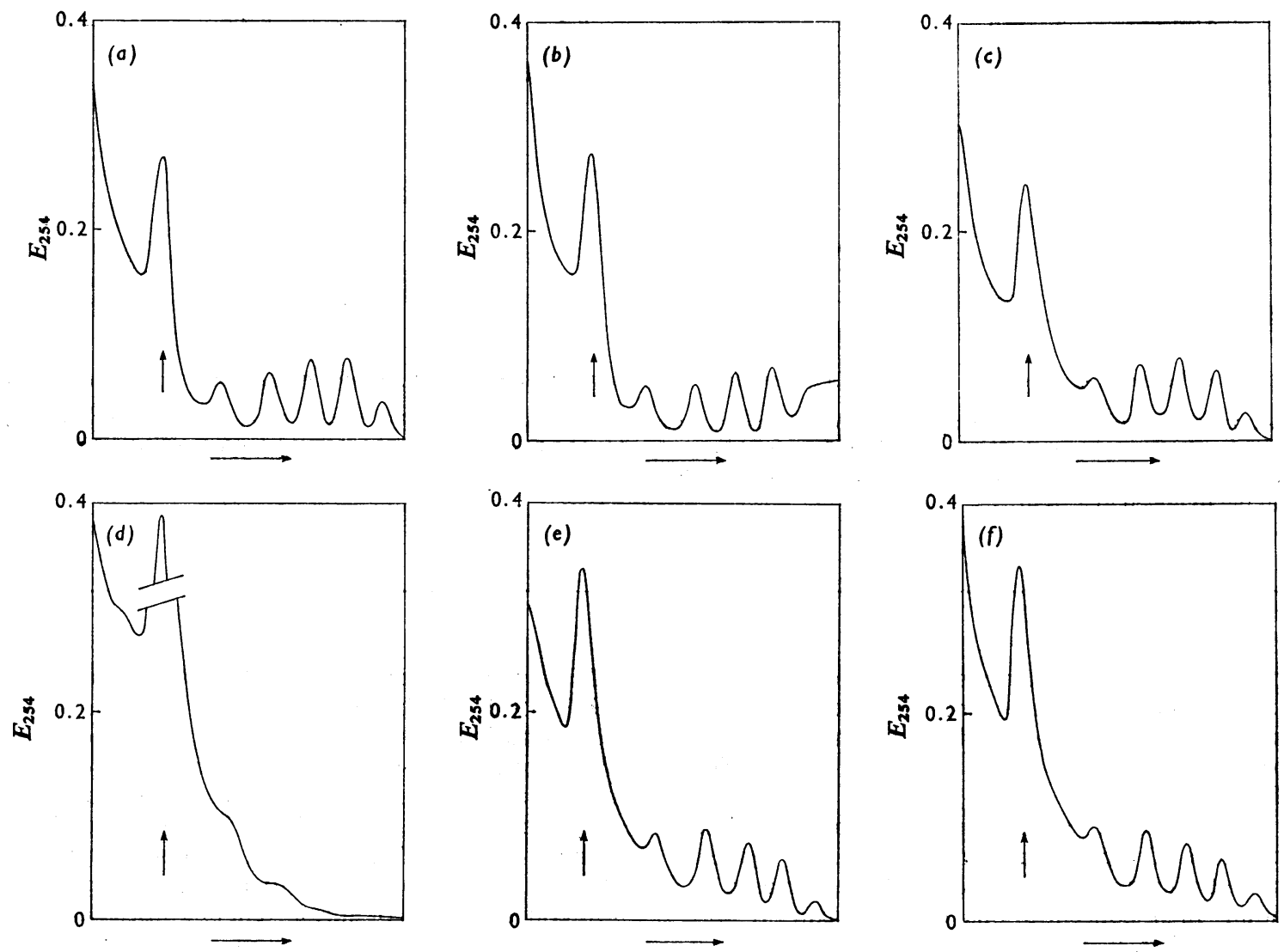

Fig. 3. Effects of anisomycin and pactamycin on polyribosome profiles in reticulocyte lysates

Incubation conditions were as described under Fig. 2, with drugs added at $1 \mathrm{~min}$. For (a)-(e) samples were removed after $15 \mathrm{~min}$ incubation but after $30 \mathrm{~min}$ incubation for $(f)$. Polyribosome profiles were determined as under Fig. 2. (a) $40 \mu \mathrm{g}$ of anisomycin $/ \mathrm{ml}$; (b) $0.1 \mu \mathrm{g}$ of anisomycin $/ \mathrm{ml}$; (c) $200 \mu \mathrm{g}$ of pactamycin $/ \mathrm{ml}$; (d) $0.25 \mu \mathrm{g}$ of $\mathrm{pactamycin} / \mathrm{ml}$; (e) $20 \mu \mathrm{g}$ of pactamycin $/ \mathrm{ml}$; $(f) 20 \mu \mathrm{g}$ of pactamycin $/ \mathrm{ml}$.

siderably greater than that observed with low concentrations of trichodermin (cf. Fig. $2 c$ ).

We then decided to investigate other concentrations of pactamycin to see whether we could observe an effect intermediate between extensive 'run off' and stabilization, similar, in fact, to that shown by low concentrations of trichodermin. Figs. 3(e) and $3(f)$ illustrate profiles at 15 and $30 \mathrm{~min}$, respectively, of samples previously treated with pactamycin $(20 \mu \mathrm{g} / \mathrm{ml})$ added at $1 \mathrm{~min}$. An initial partial breakdown (30-35\%) was observed for the polyribosome profile, followed by an apparent stabilization. This effect is qualitatively identical with that shown at low trichodermin concentrations, although at this pactamycin concentration $(20 \mu \mathrm{g} / \mathrm{ml})$ the time-course shows $97 \%$ inhibition of protein synthesis.
We then compared the effect of low trichodermin concentrations with the effect produced by $\mathrm{T}-2$ toxin, a related 12,13-epoxytrichothecene which, as an inhibitor of initiation, induces extensive 'run off' in the reticulocyte cell-free system. Fig. 4(a) shows that after just 1 min treatment with low concentrations of trichodermin, the same extent of polyribosome breakdown is observed as after $15 \mathrm{~min}$ in the presence of the drug (cf. Fig. $2 c$ ), indicating that any 'run off' effect is maximum within this first minute. For comparison, Fig. 4(b) shows that the extent of polyribosome breakdown after $1 \mathrm{~min}$ treatment with $\mathrm{T}-2$ toxin $(25 \mu \mathrm{g} / \mathrm{ml})$ is virtually identical with that observed with the low concentration of trichodermin (Fig. 4a), although T-2 toxin induces total 'run off' over $14 \mathrm{~min}$ incubation (Fig. 4c). Our results strongly suggest, therefore, that at low trichodermin 

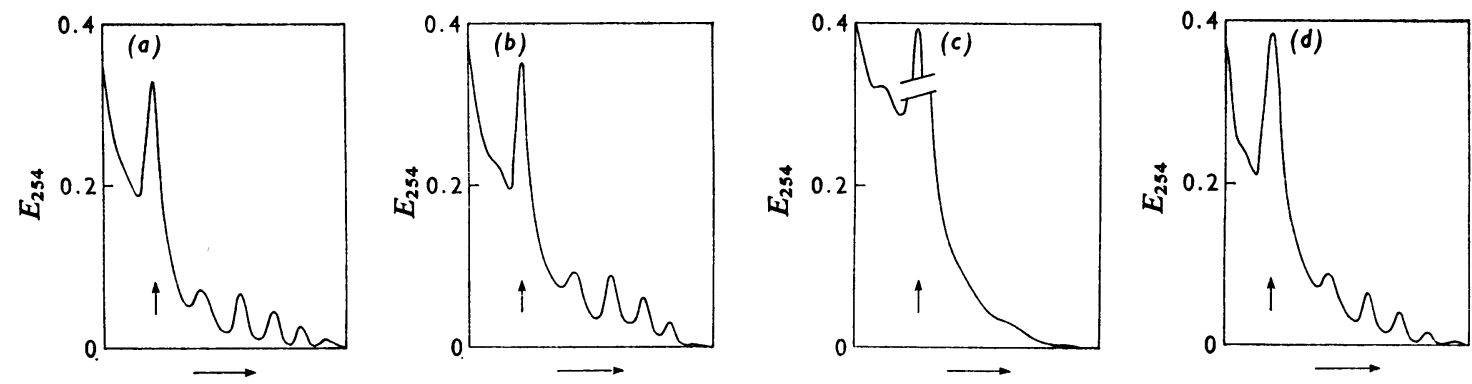

Fig. 4. Effects of T-2 toxin and trichodermin either singly or in combination on polyribosome profiles in reticulocyte lysates

Incubation conditions and analysis of polyribosomes were as described under Fig. 2. (a) Trichodermin $(0.25 \mu \mathrm{g} / \mathrm{ml})$ added at $1 \mathrm{~min}$ and sampled at $2 \mathrm{~min} ;(b) \mathrm{T}-2$ toxin $(25 \mu \mathrm{g} / \mathrm{ml})$ added at $1 \mathrm{~min}$ and sampled at $2 \mathrm{~min} ;(c) \mathrm{T}-2$ toxin $(25 \mu \mathrm{g} / \mathrm{ml})$ added at $1 \mathrm{~min}$ and sampled at $15 \mathrm{~min} ;(d)$ trichodermin $(0.25 \mu \mathrm{g} / \mathrm{ml})$ added at $1 \mathrm{~min}, \mathrm{~T}-2$ toxin $(25 \mu \mathrm{g} / \mathrm{ml})$ added at $2 \mathrm{~min}$, sample removed at $15 \mathrm{~min}$.

concentrations an initial ribosome 'run off', occurring within $1 \mathrm{~min}$, takes place and that the 'run off' is as efficient as that induced by much higher $\mathrm{T}-2$ toxin concentrations over the same time-period of $1 \mathrm{~min}$.

Finally, further experiments were performed to determine if the partial 'run off' induced by low concentrations of trichodermin could be increased by adding high concentrations of T-2 toxin. It was observed that, if the sample was treated with $0.25 \mu \mathrm{g}$ of trichodermin $/ \mathrm{ml}$ for $1 \mathrm{~min}$ before the addition of $25 \mu \mathrm{g}$ of T-2 toxin/ml, very little additional 'run off' occurred over a period of $13 \mathrm{~min}$ incubation (cf. Figs. $2 c, 4 a, 4 c$ and $4 d$ ). The implications of this result will be considered shortly.

From our overall observations it is clear that high concentrations of trichodermin inhibit protein synthesis in a way that is consistent with efficient interaction at the peptidyl transferase catalytic centre. Thus the drug behaves similarly to anisomycin, a known peptidyl transferase inhibitor, in stabilizing polyribosome profiles totally when added to a reticulocyte cell-free system. High concentrations of pactamycin produce the same result and the kinetics of inhibition of protein synthesis displayed by all three drugs at high concentration (cf. Fig. 1c) show an immediate effect on drug addition, indicating an instantaneous inhibition of elongation. Further, this interpretation is completely in line with the many reports in the literature which show that trichodermin can be used in a variety of systems in vitro to inhibit the peptidyl transferase reaction assayed in isolation (Carrasco et al., 1973; Tate \& Caskey, 1973; Schindler, 1974).

In principle it is possible to cause up to $50 \%$ maximum breakdown of polyribosomes with any inhibitor of polypeptide chain elongation (Cundliffe, 1967, 1972). Such an effect could occur at drug concentrations optimum for one hit/polyribosome. We have indeed observed that at low trichodermin concentrations there is a certain amount of polyribosome breakdown (30-35\%) before stabilization of the profile. Theoretically, this could represent the sort of situation alluded to above, although with low concentrations of anisomycin (a known peptidyl transferase inhibitor) this effect is not produced. Neither is the effect produced with low concentrations $(0.25 \mu \mathrm{g} / \mathrm{ml})$ of pactamycin, where extensive 'run off' is observed. Further, the hypothesis requires that once the maximum (50\%) breakdown is reached the remaining polyribosome profile should be maintained, but in the absence of any further protein synthesis. In our experiments this is clearly not the case, since the time-courses show that residual protein synthesis occurs at trichodermin concentrations that allow 'run off'/stabilization. Our ability to obtain similar 'run off'/stabilization profiles with a selected concentration of pactamycin suggests that the two drugs, at critical concentrations, could have dual roles as protein-synthesis inhibitors, affecting initiation primarily and elongation secondarily. With low concentrations of trichodermin we suggest therefore that the steady-state situation could result from an initial 'leaky' initiation effect followed within a minute by a secondary 'leaky' elongation effect, the final steady state being a combination of the two. The effect on elongation would be expected to include a comparable effect on the termination reaction, itself a step involving peptidyl transferase. Initiation cannot be $100 \%$ inhibited, otherwise residual protein synthesis would not be linear and the rate would 
decline with time; also polyribosomes would 'run off' completely. Similarly, elongation cannot be $100 \%$ inhibited, otherwise no residual protein synthesis would occur. We suggest that initially trichodermin, added at low concentration, associates with ribosomes recently initiated, possibly because of a somewhat easier access to its site of action. There is an important precedent for this type of preferred binding, since T-2 toxin, a structurally related drug, is excluded from functional interaction with its ribosomal binding site by peptidyl-tRNA containing more than a certain number of amino acid residues (M. Cannon \& K. E. Smith, unpublished work). Within $1 \mathrm{~min}$ of trichodermin addition, however, the drug appears to exert an additional effect by slowing down elongation, presumably by inhibition at the peptidyl transferase centre, but allowing some residual synthesis. This may indicate that the drug can bind to ribosomes further along mRNA but that this binding is somewhat rate-limiting. At high concentrations of trichodermin the drug presumably binds to all ribosomes efficiently, and elongation is inhibited $100 \%$ and instantaneously. 'Run off' cannot occur and in any case initiation would be expected also to be $100 \%$ inhibited.

The inhibitory response to pactamycin requires further comment. At $0.25 \mu \mathrm{g} / \mathrm{ml}$, inhibition of total protein synthesis shows a short lag, followed by a linear phase during which the rate of inhibition is $70-75 \%$. This linear rate declines with time (Fig. 1c), since inhibition at the initiation level becomes increasingly rate-limiting as more and more ribosomes 'run off' from mRNA. With this concentration of pactamycin, polyribosome breakdown is extensive but not absolutely complete over $14 \mathrm{~min}$ incubation (cf. Figs. $3 d$ and $4 c$ ). Thus initiation is not totally inhibited, although this step is clearly inhibited more efficiently than is elongation. Pactamycin $(20 \mu \mathrm{g} / \mathrm{ml})$ inhibits initiation very efficiently and the secondary inhibition of elongation occurs more quickly and more completely (cf. trichodermin at low concentration) than at the lower concentration $(0.25 \mu \mathrm{g} / \mathrm{ml})$. Hence the initial 'run off' (30-35\%), followed by stabilization, resulting in the high degree of inhibition of protein synthesis $(97 \%)$. We emphasize that the relative inhibition by pactamycin of initiation and elongation is critically dependent on the drug concentration and that the balance between the two inhibitory responses is very fine. Thus Lodish et al. (1971) have indicated that even at the lowest concentration of pactamycin needed to block initiation completely there is still a twofold decrease in the rate of chain propagation.

The above considerations could explain the results of our experiments that polyribosomes pretreated with trichodermin $(0.25 \mu \mathrm{g} / \mathrm{ml})$ do not 'run off' significantly more when subsequently exposed to $\mathrm{T}-2$ toxin $(25 \mu \mathrm{g} / \mathrm{ml})$. The presence of trichodermin bound to ribosomes, particularly monomers, even in 'leaky' fashion may be sufficient to exclude any additional functional interaction with added T-2 toxin.

The absolutely reproducible nature of our experiments and the extreme clarity of our polyribosome profiles allows us to emphasize that our results show categorically that in reticulocyte lysates, used under the conditions specified here, no build-up of polyribosomes occurs in the presence of any concentration of trichodermin tested. Such a build-up would be expected if the antibiotic inhibited, preferentially, the termination process in vitro. This would be particularly so in our system where initiation is occurring. Wei et al. (1974) have claimed that, in vitro, anisomycin acts primarily on elongation, whereas trichodermin acts primarily on termination. We cannot agree with this interpretation for trichodermin. These workers compared the effects of the different antibiotics both on the polypeptide-chain termination assay in vitro (Tate \& Caskey, 1973), and on poly(U)-directed phenylalanine incorporation using the reticulocyte cell-free system. The two assays they used are not directly comparable and it is sometimes unwise to extrapolate from results using poly(U). Thus although Wei et al. (1974) obtained a maximum inhibition by trichodermin of only $50 \%$ in the poly(U) system, Schindler (1974) has claimed a maximum of $13 \%$ inhibition. In contrast we have obtained approximately $70 \%$ inhibition in a comparable system (results not shown), a similar maximum to that reported by Tate \& Caskey (1973). The inhibitory response of the poly(U) system to trichodermin is closely dependent on the $\mathrm{Mg}^{2+}$ ion concentration (C. J. Carter, unpublished results). This may explain the observations of Schindler (1974), who used $18 \mathrm{~mm}-\mathrm{Mg}^{2+}$, but not of Wei et al. (1974), who used $12 \mathrm{mM}-\mathrm{Mg}^{2+}$ (identical with ours).

Wei et al. (1974) and Stafford \& McLaughlin (1973) have also carried out noteworthy experiments in vivo using both HeLa cells and yeast. Again they have concluded that trichodermin preferentially inhibits the termination step in protein synthesis. We have not repeated their experiments and we are unable, therefore, to exclude the remote possibility that trichodermin inhibits in this way under certain selected conditions in vivo. However, we emphasize yet again that since termination reactions involve peptidyl transferase and since trichodermin is a potent inhibitor of this catalytic centre a preferential inhibition of the termination event at this level seems unlikely.

This research was supported in part by a grant from the Science Research Council to M. C. The financial support of the Medical Research Council is gratefully acknowledged by C. J. C. 


\section{References}

Bamburg, J. R. \& Strong, F. M. (1971) Microb. Toxins 7, 207-292

Carrasco, L., Barbacid, M. \& Vazquez, D. (1973) Biochim. Biophys. Acta 312, 368-376

Cundliffe, E. (1967) Mol. Pharmacol. 3, 401-411

Cundliffe, E. (1972) in Molecular Basis of Antibiotic Action (Gale, E. F., Cundliffe, E., Reynolds, P. E., Richmond, M. H. \& Waring, M. J., eds.), pp. 278-379, WileyInterscience, New York

Cundliffe, E., Cannon, M. \& Davies, J. E. (1974) Proc. Natl. Acad. Sci. U.S.A. 71, 30-34

Grollman, A. P. (1967) J. Biol. Chem. 242, 3226-3233

Lodish, H. F., Housman, D. \& Jacobsen, M. (1971) Biochemistry 10, 2348-2356
Schindler, D. (1974) Nature (London) 249, 38-41

Smith, K. E., Cannon, M. \& Cundliffe, E. (1975) FEBS Lett. 50, 8-12

Stafford, M. E. \& McLaughlin, C. S. (1973)J. Cell. Physiol. 82, 121-128

Stewart-Blair, M. L., Yanowitz, I. S. \& Goldberg, I. H. (1971) Biochemistry 10, 4198-4206

Tate, W. P. \& Caskey, C. T. (1973) J. Biol. Chem. 248, 7970-7972

Ueno, Y. (1970) Proc. U.S. Jpn. Conf. Toxic Micro-org. (Herzberg, M., ed.), pp. 76-79

Wei, C. M., Hansen, B. S., Vaughan, M. H., Jr. \& McLaughlin, C. S. (1974) Proc. Natl. Acad. Sci. U.S.A. 71, 713-717 